\title{
The Application of Interest Teaching in Higher Education
}

\author{
Huihua Zhang ${ }^{1,}$, Huasheng $\mathrm{He}^{2,}$ and $\mathrm{HaO} \mathrm{Hu}^{1, \mathrm{c}}$ \\ ${ }^{1}$ College of Science and Art, Jingdezhen Ceramic University, Jingdezhen, 333000 \\ ${ }^{2}$ Jingdezhen Ceramic University, Jingdezhen, 333000 \\ a253313652@qq.com, b297009138@qq.com, ${ }^{\mathrm{c}} 2106465339 @ q q . c o m$
}

Keyword: Interest teaching; Student's; Application

\begin{abstract}
Based on the goal of education and teaching, this essay studies the function of interest teaching method in teaching, explores and analyzes the contents of interest teaching method, and tries to promote the improvement of teaching quality through research.
\end{abstract}

\section{Introduction}

Herbert, a famous German representative of "interest education", once said, "The highest and final purpose of teaching is contained in this concept -- virtue. But the nearer aim of teaching is expressed in many interests, the nearer purpose is to achieve the final goal." [1] Under the guidance of the new era of educational philosophy, the interest teaching method is receiving more and more attention. The interesting teaching is both a teaching philosophy and a teaching art. The Interest teaching method is also one of the main means to implement the new era of educational philosophy into the actual teaching.

\section{The Goal of Education and Teaching Requires Interest Teaching}

Develop Students' Ability to Discover. The basic goal of teaching is to help students form concepts, and the key to the students' concept formation is to discover the essential attributes or laws of things. Discovery is an important form of creation. Bruner, a famous modern psychologist, holds that "discovery is not limited to the act of seeking what human beings are not aware of, and, to be exact, to discover all forms of knowledge that is acquired by one's own mind"[2]. It can be seen that it is also a discovery that students use their own brains to obtain knowledge in person. Therefore, in the process of education and teaching, teachers should strive to create the conditions to provide students with the opportunity of independent exploration. In other words, teachers must give students full space for thinking, so that students can understand the formation and development of concepts in the process of observation, experiment, induction and analysis. Teachers must rediscover the professional courses, and then create and cultivate the students' ability to discover.

Cultivate Students' Innovative Spirit. The spirit of innovation is the soul and motivation for the development of creativity. Cultivating the students ' innovative spirit is the most important and effective measure to develop students' creativity. To what extent a person's creativity can be developed, whether or not he can make a creative contribution to society, depends to a large extent on whether he has the spirit of innovation [3]. If one does not want to be creative, even if he has a higher level of intelligence and higher creativity, all equal to zero; and if he has a noble character willing to contribute to the advancement of science and mankind, this will provide for the development of his creativity huge spiritual power, and then he may make a creative contribution to society. Therefore, special attention should be paid to the cultivation of students' innovative spirit in the creative teaching of professional concepts. For example, teaching can be conducted through multimedia means so that students are interested in learning new concepts and new knowledge so as to stimulate students' curiosity. Through effective means of encouragement, students are encouraged to boldly raise questions and make bold predictions and speculations. Cultivate the challenging and adventurous students; through ideological education, enable students to establish their lofty ideals of contributing to social progress, and cultivate 
the best qualities of students who love the motherland and love the people.

To Develop Students' Practical Ability. Creation is a practical activity. The practice provides the requirements for creation, the creation of standards that provide the possibility of success. Therefore, it can be said that practice is the foundation and source of creation. Only by actively participating in practice can we find new problems, put forward new ideas and new methods to grasp the opportunities of creation, create success, and then improve the creative ability. Similarly, an increase in creativity will prompt one to put new ideas into practice, develop practical habits in creative activities, and further enhance creativity. It can be seen that cultivating students 'practical ability plays an important role in improving students' creativity. This requires that in the teaching process, teachers must seize every opportunity to develop students 'practical ability, so as to achieve the purpose of improving students' creativity. [4] For example, students can be guided from the existing knowledge to explore new professional knowledge; Students can discover new concepts through practical operation, and can use the professional concepts learned to solve practical problems in daily life.

The above teaching objectives are not isolated, but interrelated, complementary and indivisible. Basic knowledge and basic skills are the basis of creative teaching, and the goal of creative teaching is the result of the development of teaching objectives. Therefore, in teaching, in addition to determining the basic objectives of teaching, one must also center the goal of cultivating creativity to create in the foundation of secondary school. In learning to consolidate the foundation, one can improve creativity.

\section{The Cognitive Characteristics of Students Determine Their Interest in the Process of Teaching}

Cognitive psychology holds that knowledge or experience exists in the form of representation in the mind, that is, certain features of the object and their relations are expressed in another form, stored in the brain, and constitutes a meaningful knowledge of the learner.

The learning process is a process of cognitive representation. Characterization is different from representation, which is not only the reflection of objective things, but also the processed object. In the process of learning, students change the external things, including the characteristics, shapes, quantities and colors of things, into the psychological fact in the body by perceiving and perceiving. The psychological fact here is the number and shape. Students' cognitive representation develops by the age of the individual and is divided into three stages: action representation, representation, symbolic representation. University student learning is mainly symbolic representation, that is, can use symbols (mainly language), to reproduce their inner world, in order to gain knowledge. These symbols are not direct things, but abstract, indirect and logically strong knowledge. This kind of knowledge obtained through cognitive representation forms a certain system in the minds of students, that is, students' intrinsic learning outcomes are the cognitive structures of students' minds.[5]

From the cognitive structure of students' learning, it is of great significance to study the students' learning characteristics, learning styles and learning effects. Especially in today's situation of advocating students' self-exploration and innovative learning mode, more attention should be paid to the design of teaching methods to make teaching more in line with the cognitive structure of students so that students can have fun and feel relaxed while studying courses, So that they can really learn useful, valuable knowledge of their own and really appreciate the importance of the curriculum.

\section{Analysis of the Application of Interest Teaching Method in Higher Education}

Teaching Props Should Arouse Students' Interest. To make students more familiar with the knowledge in the classroom, teachers need to rely on the teaching tools - to make students interested in teaching tools. For example, teaching small sticks is a favorite of students in the1990s, but now everyone has no interest in small wooden sticks. If you continue to use this kind of prop, you may be counterproductive and fail to meet the teaching objectives. Teaching props need to be based on professional characteristics to choose the most suitable tools, such as multimedia and so on.

To Allow Students to Participate in the Teaching Process, Increase Their Interest. The classroom is not only the stage of the teacher, but also the home of the students. If the students participate not only is 
our classroom full of vitality, but also the teaching effect has been fully improved. For example, taking out of parts or modules in the actual teaching process, let students experience the process of preparing lessons, teaching. By doing so, students practice their ability to, and students can also discover their interest in participating in the process of teaching.

Use Multimedia Technology Teaching to Improve Students' Interest in Learning. With the extensive integration of "Internet + " in various fields of society, the modern educational technology marked by multimedia and network communication technologies has been widely used in teaching. It can promote the rapid updating of teaching content, make the teaching method vivid and better cultivate students' thinking, imagination and creativity; and play an active role in spreading and reusing teaching resources. In recent years, the pace of development of multimedia computer-aided instruction has been staggering. Many teachers are actively learning and using this technology and have summed up many successful experiences. [6]

Contact with the Real Life to Promote Interest Training. Teaching should be closely linked with life, mining knowledge of life connotation, so that classroom knowledge is more closely linked to reality. Teachers should make rational use of multimedia technology to create a vivid, visual, and audiovisual teaching environment for students to create a good atmosphere for learning so as to help students understand the problem structure, clear the text barriers, form a space concept, and smoothly achieve the teaching aims.

Expand the Thinking Space, Promote Personality Development. The rapid development and use of modern networks provide students with the maximum room for their thinking activities and allow students to fully display their individuality, expands their wings of thinking. While deepening their understanding of majors, students can also see the flash of creative thinking.

Guide Active Participation and Promote Efficiency Improvement. Learning content in the game or competition can help students liberate themselves from boredom, arouse their enthusiasm to actively participate in practice; teaching will yield twice the result with half the effort. Teachers can take full advantage of the computer that has the characteristics of playing games, so that students develop intelligence in the game, arousing the interest of students to pursue the psychological success once again. The use of advanced technology can improve the efficiency of the classroom, and can also enhance student interest in education and teaching.

\section{Conclusion}

The new era of higher education should be consistent with the new era of college students, which is the focus of student-centered expression. Interest is the best teacher to learn. Exploring the students' interest in learning and the use of non-lagging interest in teaching is the key to education and teaching.

\section{References}

[1] J.H.Chong.On the teaching of "interest" class interest [J]. Brand (second half). 2015 (04)

[2] S. Ning, H.Jiang, L.Chen, W.F Chen, J.X Xie. The use of interest teaching method in interactive physiology classroom [J]. Northwestern Medical Education. 2013 (06)

[3] C.Luo. Inspiration of Herbart's interest teaching thought [J]. Journal of Hexi University 2013 (04)

[4] G.Guo.Evolution history of western interest education thought [J]. China Education Science. 2013 (01)

[5] Tomlinson, X.Y Li. Interpretation of Herbart's thought of interest education [J]. knowledge economy. 2017 (16)

[6] M Zhang. Refining "real problems", practicing "real kung fu", being a "good teacher" of Ideological and political education, [J]. Beijing Education (Higher Education). 2017 (03) 